\title{
Analysis of Land Suitability Level and Efficiency of Corn Farming Business in Kempo District, Dompu
}

\author{
Dedy Maskumambang1*, Bambang Dipokusumo ${ }^{1}$, L. Sukardi ${ }^{1}$ \\ ${ }^{1}$ Masters Program in Dry Land Resource Management, Postgraduate University of Mataram, Indonesia.
}

DOI: 10.29303 /jppipa.v7iSpeciallssue. 963

\section{Article Info}

Received: September $14^{\text {th }}, 2021$

Revised: December $16^{\text {th }}, 2021$

Accepted: December 22th 2021

\begin{abstract}
The development of corn plants should pay attention to the level of land suitability and the resulting economic value. This study aims to evaluate the level of land suitability and efficiency of corn farming in Kempo District so that the results can be used as a reference in making agricultural decisions, especially for the development of corn plants. The research was conducted in the Kempo District, Dompu Regency, West Nusa Tenggara. The research method used is a survey method. The results showed that there was corn farming land cultivated in the land suitability class that was not suitable $(\mathrm{N})$ of 9.30 ha $(0.05 \%)$, according to marginal (S3) covering an area of 8,634.94 ha (45.05\%), sufficient suitable (S2) covering an area of 6,841.55 (35.70\%) and very suitable (S1) covering an area of $1,086.59(5.67 \%)$. Corn farmers who cultivate land for corn farming in land suitability class $\mathrm{N}$, farmers incur costs that are higher than the total revenue from corn, the average respondent loses, this is not realized by the farmers concerned, while the highest level of farming efficiency is shown in exploitation land class is very suitable (S1) followed by class S2 and then S3. Based on the results of this study, it is recommended that farmers not cultivate corn on land that is categorized as unsuitable, while on land that is categorized as quite suitable (S2) and marginally suitable (S3), land engineering efforts are needed according to their respective limiting factors to increase the level of suitability be more suitable. While the highest level of farming efficiency was shown in the very appropriate class (S1), followed by the S2 class and then the S3 class.
\end{abstract}

Keywords: Analysis; Land suitability; Economy; Corn

Citation: Maskumambang, D., Dipokusumo, B., \& Sukardi, L. (2021). Analysis of Land Suitability Level and Efficiency of Corn Farming Business in Kempo District, Dompu. Jurnal Penelitian Pendidikan IPA, 7(SpecialIssue), 351-358. https://doi.org/10.29303/jppipa.v7iSpecialIssue.963

\section{Introduction}

The maize harvested area of NTB in 2018 was 326,377 ha with a production yield of 2,084,929 tons, so the average production per hectare or productivity was only 6,338 tons/ha (BPS NTB, 2019). The productivity of maize in NTB is still low when compared to other countries such as the United States, which has productivity of 9.77 tons/ha (FAO, 2012).

Kempo District, Dompu District, is one of the largest maize-producing districts in NTB. The area of corn planted in Kempo District in 2018 is 1,260.7 ha in paddy fields and 11,920 ha in dryland (BPS Kabupaten
Dompu, 2019). This shows that more than $68 \%$ of the land in Kempo District is planted with corn, of which the Kempo District area is 19,167 ha (BPS Kabupaten Dompu, 2019).

Looking at the data on maize productivity in NTB and the extensive maize planted area in Kempo District, it shows that the high maize production in NTB is not caused by land productivity for maize but is caused by the increase in the area of maize cultivation. The addition of a corn-planted area often does not consider the land suitability factor.

The suitability of land for agricultural land is important to know by comparing the requirements for 
growing crops with land conditions. According to Kebede, et al., (2021) land suitability is the suitability of land for a particular use. Land suitability is more specific when viewed from the physical characteristics of the environment, such as climate, soil, topography, hydrology, and drainage, which are suitable for farming certain productive crops (Everest, et al., 2021). The suitability class of an area can differ depending on the type of land use being considered (Mazahreh, et al., 2019).

To obtain the suitability of land for a plant commodity, a land evaluation is carried out (Samsur, et al., 2020). Land suitability includes two important things, namely actual and potential suitability (Rahmawaty, et al., 2019).

This study aims to evaluate the level of land suitability for corn plants and provide recommendations for land management for corn plants in Kempo District, Dompu Regency. The results of this study are also expected to be a reference for local governments in agricultural development planning as well as decision-making materials on the development of corn crop commodities that are oriented to the carrying capacity of the land and the development of sustainable agricultural land.

\section{Method}

The research location was carried out in Kempo District, Dompu Regency, West Nusa Tenggara Province.

The research method used is a land survey method and interviews with respondent farmers, totaling 35 of the largest samples in all classes. Determination of the location of the sample is determined by proportional sampling, while the determination of the number of respondents by random sampling is determined by 5 people in each village in Kempo District.
The analysis method uses the modified matching method of land suitability criteria for maize according to Djaenuddin, et al (2003) and Muhsoni (2013), while the land productivity analysis method compares land area with production results, as shown in the following formula:

$$
\text { Corn Bag Production }=\frac{\text { Com Production }[\text { Ton) }}{\text { Com Land Area }(H a)} \ldots . . .(1)
$$

To find out farmers' income from corn farming, a cost and revenue analysis was used, with the following formula (Siswo, et al, 2005):

$\mathrm{I}=\mathrm{TR}-\mathrm{TC}$

$$
\begin{aligned}
& \text { Description: } \\
& \begin{array}{ll}
\mathrm{I} \quad=\text { net income }(\mathrm{Rp}) \\
\mathrm{TR} & =\text { Total revenue }(\mathrm{Rp}) \\
\mathrm{TC} & =\text { Total cost }(\mathrm{Rp})
\end{array}
\end{aligned}
$$

To determine the level of efficiency managed by farmers, the following Revenue Cost Ratio analysis was used (Soekartawi, 1995 in Nurhayati, 2002):

$$
\begin{aligned}
& \text { R/CRatia }=\frac{\text { Total revenue }(\mathrm{TR})}{\text { Total expenses }(\mathrm{TE})} \ldots . . . . \\
& \begin{array}{ll}
\text { Description: } & \\
\text { R/C Ratio } & =\text { Revenue Cost Ratio } \\
\text { TR } & =\text { Total revenue } \\
\text { TE } & =\text { Total expenses }
\end{array}
\end{aligned}
$$

Decision criteria:

\begin{tabular}{|c|c|}
\hline Land Suitability Class & FAO Framework Explanation \\
\hline S1 class, very suitable & $\begin{array}{l}\text { Land does not have significant or significant limiting factors on sustainable use, or minor } \\
\text { limiting factors that will not significantly reduce land productivity. }\end{array}$ \\
\hline S2 class, quite appropriate & $\begin{array}{l}\text { Land has a limiting factor, and this limiting factor will affect its productivity, requiring } \\
\text { additional inputs. These barriers can usually be overcome by the farmers themselves. }\end{array}$ \\
\hline cording to mar & $\begin{array}{l}\text { Land has a severe limiting factor, and this limiting factor will affect its productivity, } \\
\text { requiring more additional inputs than land classified as S2. To overcome the limiting factors } \\
\text { in S3 requires high capital, so that there is a need for assistance or intervention (intervention) } \\
\text { by the government or the private sector. Without this assistance, farmers will not be able to } \\
\text { cope. }\end{array}$ \\
\hline Class $\mathrm{N}$, not suitable & $\begin{array}{l}\text { Land that is not suitable }(\mathrm{N}) \text { because it has a very heavy limiting factor and/or is difficult to } \\
\text { overcome. }\end{array}$ \\
\hline
\end{tabular}

$\mathrm{R} / \mathrm{C}$ Ratio 1 = Farming is said to be efficient

$\mathrm{R} / \mathrm{C}$ Ratio $<1=$ Farming is said to be inefficient

The data was collected in the form of secondary data and primary data. Secondary data is in the form of maps and spatial data from related agencies, while primary data is data obtained directly during the survey. Land classification refers to the FAO framework (1976) as shown in Table 1.

Table 1. Land Suitability Classes according to the FAO Framework. 
Assessment of land suitability class for maize is presented in the form of data and maps for each suitability criteria. Based on land suitability parameters according to Djaenuddin, et al (2003) and Muhsoni,
(2013) which in this study were modified. The land suitability criteria for maize used in this study can be seen in Table 2.

Table 2. Criteria for Land Suitability for Corn Plants.

\begin{tabular}{|c|c|c|c|c|c|}
\hline \multirow{2}{*}{ Land Quality/Characteristics } & \multirow{2}{*}{ Symbol } & \multicolumn{4}{|c|}{ Land Suitability Class/Criteria } \\
\hline & & S1 & S2 & S3 & $\mathrm{N}$ \\
\hline Temperature & $(\mathrm{t})$ & & & & \\
\hline Annual average $\left({ }^{\circ} \mathrm{C}\right)$ & & $20-26$ & $>26-30$ & $>30-32-<20$ & $>32$ \\
\hline Availability of water & $(w)$ & & & & \\
\hline Average Rainfall/ Year (mm) & & $500-1200$ & $\begin{array}{l}1,200-1,600 / \\
400-500\end{array}$ & $>1600$ or $300-400$ & $<300$ \\
\hline Availability of oxygen (02), & $(\mathrm{O})$ & & & & \\
\hline Soil Drainage & & $\begin{array}{l}\text { Good/ to slightly } \\
\text { inhibited/Medium }\end{array}$ & rather fast & Slowed down/fast & $\begin{array}{l}\text { very slow, } \\
\text { very fast }\end{array}$ \\
\hline Soil texture root media & $(\mathrm{t})$ & & & & \\
\hline Texture & & $\begin{array}{l}\text { fine, slightly fine, } \\
\text { medium }\end{array}$ & $\begin{array}{l}\text { Fine sandy/ } \\
\text { grainy }\end{array}$ & rather rough & rough \\
\hline Erosion hazard & (e) & & & & \\
\hline Slope Class & & $>8$ & $8-15$ & $15-25$ & $>25$ \\
\hline flood hazard (fh) inundation & (f) & & & & \\
\hline Flood Inundation & & never flood & $\begin{array}{l}\text { mild (less than } \\
1 \text { month) }\end{array}$ & $\begin{array}{l}\text { moderate (1-3 } \\
\text { months/year) }\end{array}$ & $\begin{array}{l}\text { weight (above } \\
3 \text { months/ } \\
\text { year) }\end{array}$ \\
\hline land use & $(\mathrm{p})$ & & & & \\
\hline Land Use & & $\begin{array}{l}\text { rice fields/ } \\
\text { agricultural land }\end{array}$ & $\begin{array}{l}\text { Farms/Plantat } \\
\text { ion }\end{array}$ & $\begin{array}{l}\text { scrubland, open } \\
\text { ground, and } \\
\text { secondary dryland } \\
\text { forest }\end{array}$ & other \\
\hline
\end{tabular}

Each theme of land characteristics is overlaid with a map of administrative boundaries to determine the area, distribution, and percentage of each land suitability class. The assessment is carried out by adding fields or classification descriptions and providing coding on the attribute data resulting from the overlay using the field calculator tool in the ArcGis program. To calculate the area of each land suitability class, calculate geometry tools are used.

The overlay of regional boundaries with each theme of land characteristics produces seven themes of land suitability maps, all of these themes are overlaid completely so that the distribution of land suitability classes is obtained as a whole resulting in an actual map of land suitability for maize crops. Land suitability class assessment at this stage uses the minimum law, namely matching between land quality or land characteristics as a parameter with land suitability class criteria that have been compiled based on use requirements or growing requirements for corn, where the determination of suitability class is based on the lowest land suitability class of the land suitability class. seven land suitability themes that were compiled previously.

The next stage is digitizing the seven spot aerial photos in 2018 combined with the data from the land survey to find out which Kempo District is actually planted with corn. The digitization results produce a factual map of maize land in Kempo District which is then overlaid with a map of the actual land suitability class that has been prepared previously to determine the area of each suitability class based on the factual land conditions planted with maize.

The final stage is the provision of input or recommendations for land that is included in the land suitability class quite suitable (S2) and marginally suitable land (S3) according to their respective limiting factors as input for further handling of land to make it more suitable for maize cultivation in the context of increase in productivity and sustainability of farming.

\section{Result and Discussion}

Kempo District is one of the sub-districts in Dompu Regency, West Nusa Tenggara Province. This 
sub-district is located in the western part of Dompu Regency, geographically it is located between $118^{\circ} 07^{\prime}-$ 118 23' East Longitude and $8^{\circ} 25^{\prime}-9$ 43' South Latitude and has an area of 191.67 km2 (BPS Dompu Regency, 2018). Administratively, Kempo District is divided into 8 (eight) villages, namely Taa Village, Kempo Village, Soro Village, Konte Village, Tolokalo Village, So Nggajah Village, Dorokobo Village and West Soro Village. Kempo District is one of the tropical climates like other areas in Indonesia and is influenced by 2 seasons, namely the dry season and the rainy season. The air temperature ranges from $23^{\circ} \mathrm{C}-34^{\circ} \mathrm{C}$ during the day and $20^{\circ} \mathrm{C}$ at night so that the average air temperature in Kempo District is $25.6^{\circ} \mathrm{C}$. Total rainfall during 2018 reached $944 \mathrm{~mm}$ with a total of 98 rainy days. The average monthly rainfall reaches $105 \mathrm{~mm}$ with an average monthly rainy day reaching 10 days every month (BPS Kabupaten Dompu 2019). The dominant soil type in Kempo District is the Mediterranean brown and lithosol complex, which is $9,389.31$ ha or $49.87 \%$ of the total area of Kempo District. Mediterranean soil is also commonly referred to as alfisol soil. Mediterranean is a red soil group caused by high iron content accompanied by low humus content (Wirjodihardjo, 1963).

\section{Land Suitability to Temperature ( $t$ )}

The average night and day air temperature in Kempo District is $25.6^{\circ} \mathrm{C}$ so that the temperature of Kempo District is very suitable for maize, where based on the criteria of land suitability class according to temperature quality or temperature is in the range of $20^{\circ} \mathrm{C}-26^{\circ} \mathrm{C}$, then the land suitability class of the entire Kempo District is seen from the temperature criteria included in the very appropriate class (S1). The results of this study are in line with research conducted byHarniati, et al., (2000), that the ideal temperature for corn growth is between $20^{\circ} \mathrm{C}-26^{\circ} \mathrm{C}$. According to Senawi (1999), that temperature greatly affects the development of the soil profile for maize growth, these factors determine the chemical and physical properties of the soil. High average temperatures tend to increase the speed of weathering and clay formation.

\section{Land Suitability to Water Availability (w)}

According to Wirosoedarmo, et al (2011) rainfall greatly affects the development of the soil profile through the chemical and physical properties of the soil. High rainfall tends to increase the speed of weathering and clay formation and indirectly affects the reaction of the soil. In addition, it can also lead to the leaching of alkaline cations from the soil surface layer to deeper soil layers so that the soil $\mathrm{pH}$ becomes acidic (Habibie et al., 2021).
The average annual rainfall in Kempo District is $944 \mathrm{~mm} /$ year (BPS Dompu Regency 2019). Based on the criteria for land suitability for maize (Zea mays L.) according to Djaenuddin, et al (2003) and Muhsoni (2013), land suitability for maize in Kempo District is classified as very suitable (S1), because it is in the range between 500-1200 mm/year. Hardjowigeno, et al (1993), that corn growth is heavily influenced by rainfall because it can affect the development of the soil profile through the chemical and physical properties of the soil. High rainfall tends to increase the speed of weathering and clay formation and indirectly affects the reaction of the soil. In addition, it can also lead to the leaching of alkaline cations from the soil surface layer to a deeper soil layer so that the soil $\mathrm{pH}$ will become acidic (4.5).

\section{Land Suitability Against Oxygen Availability (o)}

The results of the analysis show that in general, the Kempo sub-district is very suitable (S1) with good to moderate \& good drainage criteria with an area of 15,307 ha or $79.86 \%$ of the total area, followed by a marginally suitable class (S3) with fast drainage category covering an area of 3,779 ha $(19.72 \%)$ and at least classified as quite appropriate (S2) with the criteria for moderate category drainage covering an area of 81 ha $(0.42 \%)$.

\section{Land Suitability against Rooting Media Soil Texture (t)}

The rooting medium referred to here is soil as a medium for plant growth. According to Sudjana, et al (1991) the most suitable soil texture for corn plants is a fine texture or clay soil. Based on the results of the analysis of land suitability class classification according to soil texture classification in Kempo District, it shows that the land suitability class is very suitable (S1) covering an area of 15,373 ha $(80.21 \%)$ and quite suitable (S2) covering an area of 3,794 ha (19.79\%).

\section{Land Suitability against Erosion Hazards (e)}

Based on the slope analysis using the ArcGis program, the land area that belongs to the very suitable class (S1) for the $0-8 \%$ slope category reaches 13,251 ha or $69.13 \%$ of the total area of Kempo District. Land with moderately suitable class (S2) is 3,881 ha or $20.25 \%$ and land with marginally suitable class is 2,035 or $10.62 \%$. According to Wirosoedarmo, et al., (2011), that the characteristics of the slopes are related to the morphological characteristics of the land. Sloping topography has soil aggregates that are more stable than those with steep slopes, because in topography with steep slopes erosion often occurs so that organic matter which is the aggregate adhesive is lost so that the stability of soil aggregates becomes weak. The 
greater the slope, the velocity of runoff, and the eroding strength of the soil will increase.

\section{Land Suitability against Flood Inundation ( $f$ )}

The flood criteria used in this analysis is the incidence of flood inundation. Flood inundation in Kempo District, based on survey results, shows that inundation floods are almost rare. Flood events in Kempo District are usually runoff floods, namely floods sent from rainwater catchment areas in the upstream area which is channeled through rivers. The nature of this flood is the overflow of river water when it rains and the overflow flows in various directions around the river and is temporary only for a few moments and then recedes again.

Some agricultural lands experience inundation floods generally due to overflowing river water, some of the river water overflows which then immediately recedes to flow into the sea and partly infiltrates into the ground. The remaining water that does not flow and is absorbed lasts longer lasts for several days resulting in inundation of the land. The occurrence of inundation in Kempo District during 2019 based on a survey showed that it was only once in a certain area. Based on the results of the analysis on the ArcGis program, it shows that the area that experienced inundation for less than one month or the flooding that occurred was categorized as mild so that based on the suitability class, it was classified as quite suitable (S2) covering an area of 545 ha or only reached $2.84 \%$ of the total area that was not covered experience flooding in one year,

\section{Land Suitability for Land Use}

The results of the analysis of land suitability for corn plants based on land use criteria in Kempo District indicate that in general the Kempo District is classified as very suitable (S1) to marginally suitable (S3) there are several locations that are not suitable based on land use criteria where the location is an area settlement, primary forests, savanna and water bodies. The processed results of spatial analysis in the ArcGis program show that class (S1) covers an area of 1,261.28 ha $(6.58 \%)$, class (S2) covers an area of $8,697.19$ ha $(45.38 \%)$, class (S3) covers an area of 6,605.62 ha $(34.46 \%)$ and class $(\mathrm{N})$ covering an area of $2,602.58$ ha $(13.58 \%)$.

\section{Actual Land Suitability Analysis}

Analysis of all criteria, in this case, used 7 themes of land characteristics as previously discussed to determine the actual land suitability for maize in Kempo District.

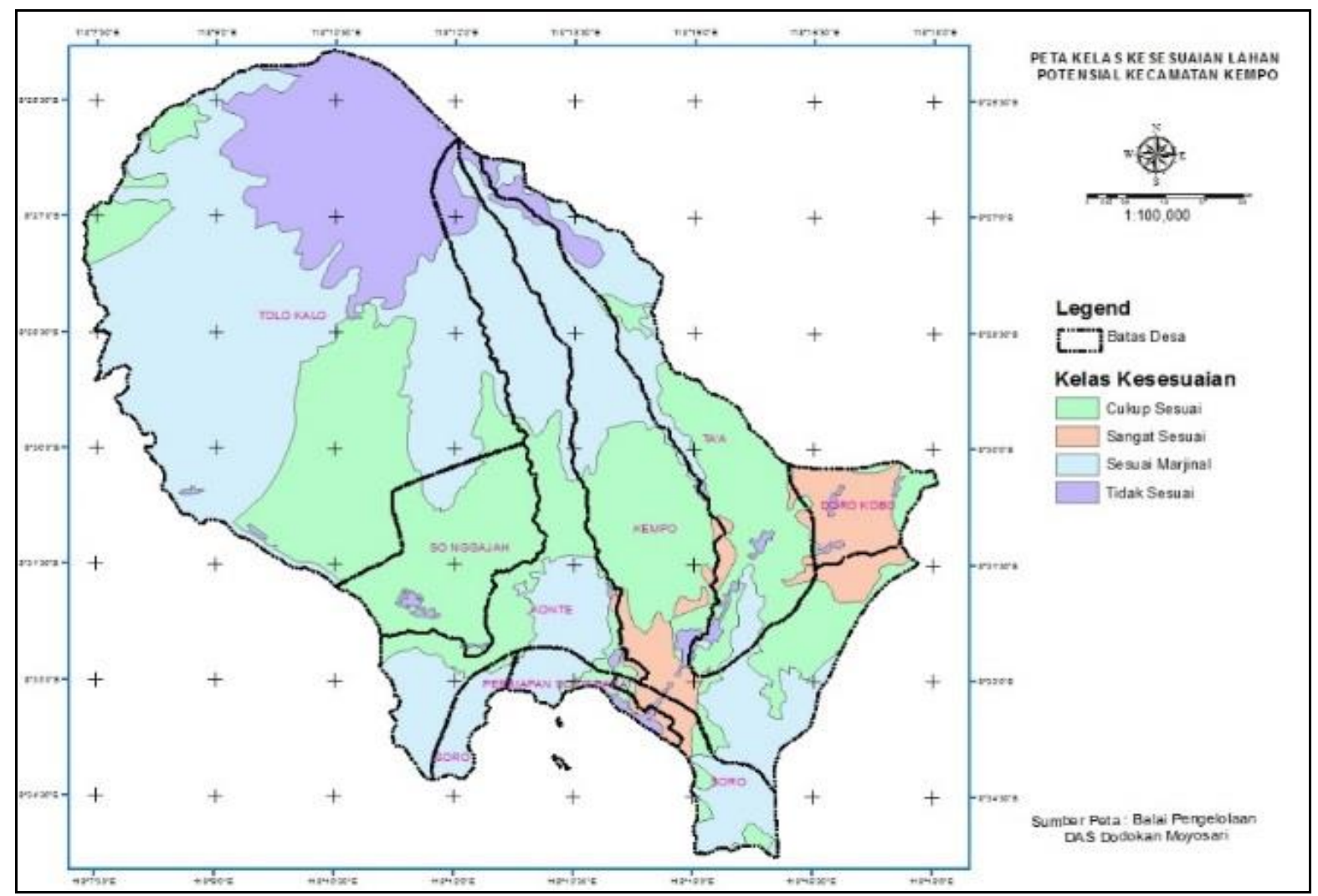

Figure 1. Map of Actual Land Suitability Class for Corn Plants According to Land Use Criteria in Kempo District 
The results of the analysis of all these criteria indicate that the land suitability class in the study area is dominated by the marginally suitable class (S3). According to the results of land analysis, the suitability class is very suitable (S1) covering an area of $1,088.59$ ha (5.68\%), quite suitable (S2) covering an area of 6,842.55 ha $(35.70 \%)$, marginally suitable (S3) covering an area of 8,631.94 $(45.04 \%)$ and not suitable $(\mathrm{N})$ covering an area of $2,603.58$ ha $(13.58 \%)$. The land suitability class data for maize in Kempo District detailed by village can be seen in Table 3, and the distribution map is as shown in Figure 1.

Table 3. Class of Actual Land Suitability in Kempo District

\begin{tabular}{|c|c|c|c|c|c|c|c|c|c|}
\hline \multirow{2}{*}{ village } & \multicolumn{8}{|c|}{ Area (Ha)/ Percentage (\%) } & \multirow{2}{*}{ Total } \\
\hline & $\mathrm{S} 1(\mathrm{Ha})$ & $\%$ & $\mathrm{~S} 2(\mathrm{Ha})$ & $\%$ & S3 (Ha) & $\%$ & $\mathrm{~N}(\mathrm{Ha})$ & $\%$ & \\
\hline Taа & 101.43 & 5.12 & 1082.12 & 54.62 & 607.21 & 30.65 & 190.50 & 9.62 & $1,981.25$ \\
\hline Kempo & 425.15 & 12.67 & $1,533.78$ & 45.72 & $1,310.46$ & 39.06 & 85.23 & 2.54 & $3,354.62$ \\
\hline contest & 24.73 & 1.03 & 725.20 & 30.31 & $1,498.25$ & 62.61 & 144.65 & 6.04 & $2,392.83$ \\
\hline Tolokalo & - & - & $2,039.18$ & 23.83 & $4,421.73$ & 51.67 & $2,096.42$ & 24.50 & $8,557.33$ \\
\hline So Elephant & - & - & $1,185.99$ & 90.98 & 88.06 & 6.76 & 29.49 & 2.26 & $1,303.54$ \\
\hline Soro West & 41.50 & 13.96 & 49.64 & 16.70 & 176.29 & 59.31 & 29.83 & 10.04 & 297.25 \\
\hline Total/Average & $1,088.59$ & 5.68 & $6,842.55$ & 35.70 & $8,631.94$ & 45.04 & $2,603.58$ & 13.58 & $19,166.6$ \\
\hline
\end{tabular}

\section{Factual Land Suitability Analysis}

From the results of the survey and digitization of the Spot 7 image map in 2018 it shows the area cultivated by the community for corn plants as large as $16,570,40$ ha $(86 \%)$ of the total area and the remaining $2,596.29$ ha $(14 \%)$ of land is designated for other uses. The results of the mapping of the area are overlaid with a map of the actual land suitability class shows that there is corn farming land cultivated in the unsuitable land suitability class $(\mathrm{N})$ which is 9.30 ha $(0.05 \%)$ located in Tolokalo Village, corn farming cultivated in the marginal appropriate land suitability class (S3) covering an area of $8,634.94$ ha $(45.05 \%)$, which is cultivated in the quite suitable land suitability class (S2) covering an area of 6,841.55 (35.70\%) and corn farming land cultivated in the very suitable land suitability class (S1) covering an area of 1,086, 59 (5.67\%).

\section{Productivity Analysis}

Data on maize productivity in each land suitability class can be presented in the following table:

Table 4. Average Land Productivity in Each Class in 2019

\begin{tabular}{lllll}
\hline \multirow{2}{*}{ Year } & \multicolumn{4}{l}{ Average Land Productivity in each class } \\
\cline { 2 - 5 } & $\mathrm{N}$ & $\mathrm{S} 3$ & $\mathrm{~S} 2$ & $\mathrm{~S} 1$ \\
& $(\mathrm{Ton} / \mathrm{Ha})$ & $(\mathrm{Ton} / \mathrm{Ha})$ & $(\mathrm{Ton} / \mathrm{Ha})$ & $($ Ton/Ha) \\
\hline 2019 & 2.80 & 5.62 & 5.99 & 7.13 \\
\hline
\end{tabular}

Table 4. shows that maize productivity in each land suitability class is different. The better the level of land suitability, the higher the productivity of the land of maize yields, with the highest productivity on S1 class land of 7.13 Tons/Ha, followed by S2 class land of $5.99 \mathrm{Tons} / \mathrm{Ha}$, then S3 class land of $5.62 \mathrm{Tons} / \mathrm{Ha}$, and the lowest on land class S3 N is 2.8 Tons/ha.

\section{Corn Farming Productivity in Each Land Suitability Class}

The results of the income analysis can be presented in Table 5.

Table 5. Corn Farming Productivity in Each Land Suitability Class

\begin{tabular}{lllll}
\hline \multirow{2}{*}{ Year } & \multicolumn{4}{l}{ Average Income (I) } \\
\cline { 2 - 5 } & $\mathrm{N}(\mathrm{Rp})$ & $\mathrm{S} 3(\mathrm{Rp})$ & $\mathrm{S} 2(\mathrm{Rp})$ & $\mathrm{S} 1(\mathrm{Rp})$ \\
\hline 2019 & $(1,666,667)$ & $14,046,667$ & $14,211,235$ & $24,758,730$ \\
\hline
\end{tabular}

Based on the Table 5. that the average productivity of corn farming in each class of land suitability, the highest obtained on land class (S1) of Rp. 24,758,730, then on the land class (S2) of Rp. 14,211,235, and on land class (S3) of Rp. 14,046,667, while in class $(\mathrm{N})$ farmers incur costs that are higher than the total revenue from corn, the average respondent loses Rp. 1,666,667,- this is not realized by the farmers concerned.

The data from the analysis of corn farming efficiency in the research area are as shown in Table 6.

Table 6. Data on the Calculation of R/C Ratio for Corn Farming in Kempo District in 2019

\begin{tabular}{lllllllll}
\hline \multirow{2}{*}{ Year } & \multicolumn{6}{l}{ R/C Ratio \& Business Efficiency } & Business & S2 \\
\cline { 2 - 8 } & $\mathrm{N}(\mathrm{Rp})$ & $\begin{array}{l}\text { Business } \\
\text { Efficiency }\end{array}$ & $\mathrm{S3}(\mathrm{Rp})$ & $\begin{array}{l}\text { Business } \\
\text { Efficiency }\end{array}$ & S1 (Rp) & $\begin{array}{l}\text { Business } \\
\text { Efficiency }\end{array}$ \\
\hline 2019 & 0.93 & In Efficient & 1.75 & Efficient & 1.75 & Efficient & 2.31 & Efficient \\
\hline
\end{tabular}


Based on the table 6 . the analysis of the highest corn farming efficiency was obtained on land class (S1) of Rp. 2.31, then on land class (S2) and land class (S3) of Rp. 1.75, as well as on land class $(\mathrm{N})$ experiencing inefficient.

\section{Land Handling Recommendations}

Each land unit has a different suitability class and different limiting factors so that in making landuse policies for corn it is advisable to refer to what factors limit the land itself so that the level of suitability is better to ensure land productivity and farming sustainability.

Some of the limiting factors that are emphasized here, which should be the focus given to land as input are the main limiting factors that cause the land to be classified as marginal according to land suitability (S3) and quite suitable class (S2), meaning that some of the limiting factors that form it can be changed or engineered as inputs to marginal land. In the research area, there is the largest marginal land suitability class recorded, meaning that here the land can be cultivated as corn farming land but must be given treatment so that it can maintain the productivity and sustainability of maize farming.

Some of the limiting factors resulting from the analysis are factors that inhibit the productivity of maize on the land according to marginal (S3) and (S2), namely: the drainage factor, that is, the soil on the land has poor drainage for maize in the drainage research area which affects the suitability of the land to be Marginal appropriate class (S3) and moderately suitable (S2) is that the soil drainage is relatively fast, this is due to the soil-forming components which contain more sand and coarse texture, the soil is porous to water which can cause the soil to lose nutrients very easily.

This poor soil drainage factor can be handled with conservation soil management, namely adding organic matter so that it helps the process of forming new soil from weathering these organic materials into the soil and improving soil structure so that the soil will contain more clay, where soil that contains a lot of clay. Clay is better able to retain water. The next factor is the erosion factor which is assessed from the land slope class. Land according to the marginal category in the study area has a limiting factor of slope because it is on a slope of $15-25 \%$.

High soil erosion results in the loss of nutrientrich topsoil. To handle land like this, soil conservation efforts are needed in the form of making terraces to engineer the land to reduce the rate of erosion. The most common terrace building on a $15-25 \%$ slope that is suitable is a bench terrace (Attachment of Minister of Forestry Regulation No. 39/pts-II/2019). Cultivation of corn on slopes of more than $15 \%$ should be carried out with a mixed system of annual crops and annual crops or with the agroforestry system, this is in accordance with the regulation of the Minister of Agriculture No. annual or agroforestry systems.

Another limiting factor is the land-use factor, where at the research location there are corn plantations that are in the marginal appropriate class with limiting land use of the secondary dryland forest. Forests as a support for human life and several functions of the forest, among others, regulate the water system. The existence of this forest is generally located on slopes above $15 \%$ so that both legal and environmental considerations for corn cultivation on steep slopes and forest areas can disrupt the ecosystem and the quality of the land itself. The area of land with this limiting factor in the study area is recorded as large enough so that efforts are needed to overcome this limiting factor by carrying out a corn planting system combined with hard plants or wood with an agroforestry system

\section{Conclusion}

The conclusion of this study is the level of land suitability for maize in Kempo sub-district is $0.05 \%$ unsuitable land, $45.05 \%$ marginal suitable, $35.70 \%$ quite suitable, and $5.67 \%$ very suitable. Corn farmers who cultivate the land for corn farming inland suitability class $\mathrm{N}$, farmers incur costs that are higher than the total revenue from corn, the average respondent loses, this is not realized by the farmers concerned, while the highest level of farming efficiency is shown in exploitation land class is very suitable (S1) followed by class S2 and then S3.

\section{References}

BPS Kabupaten Dompu. (2019). Kabupaten Dompu Dalam Angka. Dompu: BPS. [Indonesian]

BPS Propinsi Nusa Tenggara Barat. (2019). Provinsi Nusa Tenggara Barat Dalam Angka. Mataram: BPS. [Indonesian]

BPS Kabupaten Dompu. (2018). Kabupaten Dompu Dalam Angka. Dompu: BPS. [Indonesian]

Everest, T., Sungur, A., \& Özcan, H. (2021). Determination of agricultural land suitability with a multiple-criteria decision-making method in Northwestern Turkey. International Journal of Environmental Science and Technology, 18(5), 10731088. https://doi.org/10.1007/s13762-020-02869$\underline{9}$

FAO. (1996). National Forest Inventory of Indonesia: Final Forest Resources Statistics Report. Directorate General of Forest Inventory and Land Use Planning, 
Ministry of Forestry. Government of Indonesia and Food and Agriculture Organization of the United Nations, Jakarta.

Habibie, I., Noguchi, R., Shusuke, M., \& Ahamed, T. (2021). Land suitability analysis for maize production in Indonesia using satellite remote sensing and GIS-based multicriteria decision support system. GeoJournal, 1-31. https://doi.org/10.1007/s10708-019-10091-5

Hardjowigeno, S., Widiatmaka, \& Yogaswara. A.S. (1993). Soil Classification and Pedogenesis. Pressindo Academy. Jakarta.

Harniati., Marsusi, R. Sahari, D., \& Purnawati. (2000). Corn Cultivation Technology in Dry Land. Location of Pontianak Agricultural Technology Assessment. Agricultural Research and Development Agency. Pontianak Agriculture Department.

Kebede, Y. S., Endalamaw, N. T., Sinshaw, B. G., \& Atinkut, H. B. (2021). Modeling soil erosion using RUSLE and GIS at watershed level in the upper beles, Ethiopia. Environmental Challenges, 2, 100009.

https://doi.org/https://doi.org/10.1016/j.envc. $\underline{2020.100009}$

Mazahreh, S., Bsoul, M., \& Hamoor, D. A. (2019). GIS approach for assessment of land suitability for different land use alternatives in semi arid environment in Jordan: Case study ( $\mathrm{Al}$ Gadeer Alabyad-Mafraq). Information Processing in Agriculture, 6(1), 91-108. https://doi.org/https://doi.org/10.1016/j.inpa. $\underline{2018.08 .004}$

Muhsoni, F. F. (2013). Evaluasi Arahan Pemanfaatan Lahan Tambak Di Kabupaten Sampang Menggunakan Sistem Informasi Geografis. Jurnal KELAUTAN, 6(1), 9-18. https://doi.org/10.21107/jk.v6i1.828

[Indonesian]

Rahmawaty, Rauf, A., \& Frastika, S. (2019). Mapping of actual and potential land suitability for oil palm in several land unit using geographic information system. IOP Conference Series: Earth and Environmental Science, 260(1). https:// doi.org/10.1088/1755$\underline{1315 / 260 / 1 / 012073}$

Senawi. (1999). Evaluation and Land Use. Faculty of Forestry, Gadjah Mada University. Yogyakarta.

Wirosoedarmo, R., Sutanhaji, AT., Kurniati, E., and Wijayanti, R. (2011) Evaluation of Land Suitability for Corn Crops Using Spatial Analysis Methods, Journal of Agritech, 31(1). 